\title{
Mechanism of water savings and pollution reduction in paddy fields of three typical areas in southern China
}

\author{
Menghua Xiao ${ }^{1}$, Yuanyuan $\mathrm{Li}^{1,2^{*}}$, Yi J ia ${ }^{3}$, Jianwen Wang ${ }^{4}$ \\ (1. Zhejiang Institute of Hydraulics and Estuary (Zhejiang Institute of Marine Planning and Design), Hangzhou 310020, China; \\ 2. North China University of Water Resource and Electric Power, Zhengzhou 450045, China; \\ 3. Zhejiang Rural Water Conservancy Management Center, Hangzhou 310009, China; \\ 4. Qiantang River Irrigation Area Management Center, Xiaoshan District, Hangzhou City, Hangzhou 311200, China)
}

\begin{abstract}
Field irrigation and drainage regulation and fertilization application could affect water utilization and pollution transportation in a paddy field. In this study, representative rice-producing areas of Zhejiang Province in southern China were selected to study the effects of different field water level control (conventional irrigation and drainage W0, controlled irrigation and drainage W1 and W2) and different fertilization methods (2 times of fertilization F2 and three times of fertilization F3) on water irrigation quantity and consumption of rice, rice growth, water utilization, and pollution reduction. Results showed that field water level control had a great effect on irrigation quota in growing period rather than that in soaking period, and irrigation quota for W0 was 37.0\%-71.7\% higher than that for W1 and W2 in the whole growth period of rice. Although the upper limit of rain storage was greatly increased by $\mathrm{W} 1$ and $\mathrm{W} 2$, on the contrary, the yield under W1 and W2 was $0.4 \%-2.1 \%$ higher than that under W0. Water consumption, water leakage, and evapotranspiration were $16.63 \%-34.40 \%, 39.97 \%-60.80 \%$, and 9.40\%-31.53\% lower under W1 and W2 than those under W0, respectively, while it showed no significant changes under W1 and W2. Rainfall use rate and $\mathrm{WUE}_{\mathrm{I}}$ (water use efficiency of irrigation) under W1 and W2 had been significantly improved by $8.20 \%-129.58 \%$ and $31.58 \%-201.61 \%$ compared to W0. The contribution of nitrogen and phosphorus loss from surface water accounted for $90 \%$ and the total pollution load of total nitrogen (TN), $\mathrm{NO}_{3}{ }^{-}-\mathrm{N}, \mathrm{NH}_{4}{ }^{+}-\mathrm{N}$ and chemical oxygen demand (COD) were $20.0 \%-63.4 \%, 21.8 \%-66.3 \%, 21.5 \%-63.8 \%$, and $21.4 \%-46.5 \%$ lower for $\mathrm{W} 1$ and $\mathrm{W} 2$ than that for W0, respectively. Meanwhile, compared to F2, dispersed fertilization (F3) was beneficial to increase the yield and decrease pollutant load. Additionally, the path of IRA $\rightarrow \mathrm{NH}_{4}{ }^{+} \mathrm{-N} \rightarrow \mathrm{COD}$ and IRA $\rightarrow \mathrm{WCA} \rightarrow \mathrm{WUE}_{\mathrm{I}}$ presented partial remediation effect, and the effect size was $23.6 \%$ and $38.1 \%$, respectively, the path of $\mathrm{IRA} \rightarrow \mathrm{WUE}_{\mathrm{I}} \rightarrow \mathrm{WUE}_{\mathrm{ET}}$ presented a full remediation effect, and the path of IRA $\rightarrow \mathrm{WCA} \rightarrow \mathrm{WUE}_{\mathrm{ET}}$ presented suppression effect.
\end{abstract}

Keywords: controlled irrigation and drainage, water consumption, water use efficiency, non-point source pollution, structural equation mode

DOI: $10.25165 /$ j.ijabe.20221501.6092

Citation: Xiao M H, Li Y Y, Jia Y, Wang J W. Mechanism of water savings and pollution reduction in paddy fields of three typical areas in southern China. Int J Agric \& Biol Eng, 2022; 15(1): 199-207.

\section{Introduction}

Rice is one of the most important food crops in the world. Nearly $50 \%$ of the world's population takes rice as the main food. Therefore, promoting the stable and healthy development of rice production in China is an important way to achieve regional and global food security ${ }^{[1]}$. At the same time, the contradiction of water shortage in China has become increasingly prominent ${ }^{[2]}$. With the large consumption of water in industry and cities, the gap of irrigation water for agriculture has reached 60 billion $\mathrm{m}^{3}$ every

\section{Received date: 2020-08-18 Accepted date: 2021-11-21}

Biographies: Menghua Xiao, $\mathrm{PhD}$, Senior Engineer, research interest: irrigation and drainage theory and reclaimed water irrigation, Email: menghuaxiao@, aliyun.com; Yi Jia, MS, Senior Engineer, research interest: irrigation project management, Email: 25269270@qq.com; Jianwen Wang, MS, Senior Engineer, research interest: irrigation project management, Email: 444974509@qq.com.

*Corresponding author: Yuanyuan Li, PhD, Associate Professor, research interest: agricultural resources and environment, Fengqi East Rd., Hangzhou 310020, China. Tel: +86-15903662916, Email: liya66720@126.com. year, and this is increasing year by year. With unreasonable field irrigation and drainage methods, agricultural non-point source pollution is also becoming more and more serious ${ }^{[3,4]}$. Rice is a high water-consuming crop, lack of water supply will seriously limit the high and stable yield of rice ${ }^{[5]}$. The water demand of paddy rice is a comprehensive physiological and ecological index to evaluate the suitability of rice growth. Facing the increasingly severe water resources crisis, agricultural water-saving techniques on basis of improving crop water use efficiency has a great development potential ${ }^{[6]}$.

Conventional irrigation and drainage management requires large quantities of fresh water, and could cause field surface runoff when fields are over-irrigated or heavy rainfall occurs ${ }^{[7]}$. Especially in southern China, although rainfall is abundant, most of the rainwater is wasted through paddy field runoff and ground leakage, and a large amount of nitrogen and phosphorus elements entered into the ambient water bodies, resulting in low rainwater use efficiency and non-point source pollution ${ }^{[8,9]}$. Field water level control is the key to realizing the joint water-saving 
irrigation and controlled drainage by regulating soil moisture and increasing rain storage in field surface ${ }^{[10]}$ to reduce irrigation frequency and irrigation amount ${ }^{[11]}$, and also reduce pollution reduction $^{[12]}$ and improve rainfall use efficiency ${ }^{[13]}$, which has become a hot spot in the field of agricultural soil and water engineering. $\mathrm{Li}$ et al. ${ }^{[14]}$ found that the rainfall storage irrigation treatment showed a better rainfall and water use efficiency compared to conventional irrigation. Omer et al. ${ }^{[15]}$ studied the impact of water level regulation on the paddy field nutrient runoff through mathematical simulation, and the results showed that the water level regulation model can effectively reduce the net runoff load of total nitrogen and total phosphorus by reducing irrigation water in a paddy field, and also could reduce nutrient runoff loss by controlling surface drainage. $\mathrm{Gao}^{[16]}$ found that, when the upper limit of rain storage was increased to $200 \mathrm{~mm}$, the irrigation water volume was decreased by $9.7 \%-37.1 \%$, while water use efficiency of irrigation was increased by $14.6 \%-51.5 \%$, and grain yield was increased by $3.5 \%$. Shao et al. ${ }^{[17]}$ found that controlled irrigation and drainage reduced drainage volume by $15.8 \%-31.3 \%$ and increased the efficiency of available rainfall and irrigation by $1.98 \%-3.46 \%$. Xiao et al. ${ }^{[18]}$ found that the $\mathrm{NH}_{4}{ }^{+}-\mathrm{N}$ and $\mathrm{NO}_{3}{ }^{-} \mathrm{N}$ concentration was decreased by $55.56 \%$ and $42.81 \%$ respectively after $5 \mathrm{~d}$ of flooding after rainstorm under the condition of collaborative regulation on irrigation and drainage. Kroger et al. ${ }^{[19]}$ studied in the Mississippi River Delta showed that the controlled drainage can intercept $47.0 \%$ of the phosphorus in the farmland drainage, reducing the phosphorus loss to $2.4 \%$ of the farmland fertilization.

At present, a lot of research has been done on the response and regulation mechanism of irrigation and drainage regulation to rice water demand, growth characteristics and fertilizer loss, but most of them are aimed at specific areas with the same geographical characteristics. However, in different areas, the regulation of field water level is different due to different soil characteristics and topographic characteristics. Therefore, in this study, three typical areas in southern China were selected, including hilly area, coastal plain area and plain river network area, and the corresponding field irrigation and drainage water level regulation was selected in different typical areas. This study aimed to analyze the impact of field water level regulation on irrigation and water consumption, water use efficiency, crop growth and yield, pollution reduction from subsurface and groundwater in paddy fields. Additionally, the structural equation model (SEM) was established to deeply analyze the mechanism of water savings and pollution reduction in paddy fields. The research results have important theoretical and practical significance for formulating scientific and reasonable field irrigation and drainage management model, which could provide instruction for solving the contradiction between supply and demand of water resources and reducing non-point source pollution of rice irrigation areas in southern China.

\section{Materials and methods}

\subsection{Experimental site}

The experiment was conducted at three key irrigation experiment stations in Zhejiang Province from 2017 to 2019 . The experimental areas are located at Jinhua $\left(119^{\circ} 58^{\prime} \mathrm{E}, 28^{\circ} 56^{\prime} \mathrm{N}\right)$, Taizhou $\left(121^{\circ} 30^{\prime} \mathrm{E}, 28^{\circ} 30^{\prime} \mathrm{N}\right)$ and Jiaxing $\left(121^{\circ} 10^{\prime} \mathrm{E}, 30^{\circ} 43^{\prime} \mathrm{N}\right)$ respectively, which can represent the basic situation of the three major crop-producing areas of the hilly area in Central Zhejiang, the coastal plain area in Eastern Zhejiang and the plain river network area in Northern Zhejiang plain. The locations of experiment stations are shown in Figure 1. The average annual precipitation is $1170-1669 \mathrm{~mm}$, the average temperature is $17.5^{\circ} \mathrm{C}-24.0^{\circ} \mathrm{C}$, the frost-free period is $225-245 \mathrm{~d}$, the annual relative humidity is $68 \%-82 \%$, and the annual sunshine is 1909-2037 h. The soil is loam, with a $\mathrm{pH}$ value of 5.2-6.0, bulk density of $1.1-1.5 \mathrm{~g} / \mathrm{cm}^{3}$, total nitrogen of $2.1-2.6 \mathrm{~g} / \mathrm{kg}$, organic matter of $36.2-38.0 \mathrm{~g} / \mathrm{kg}$, available phosphorus of $8.6 \mathrm{mg} / \mathrm{kg}$, and exchangeable potassium of $59.5-61.2 \mathrm{~kg} / \mathrm{kg}$.

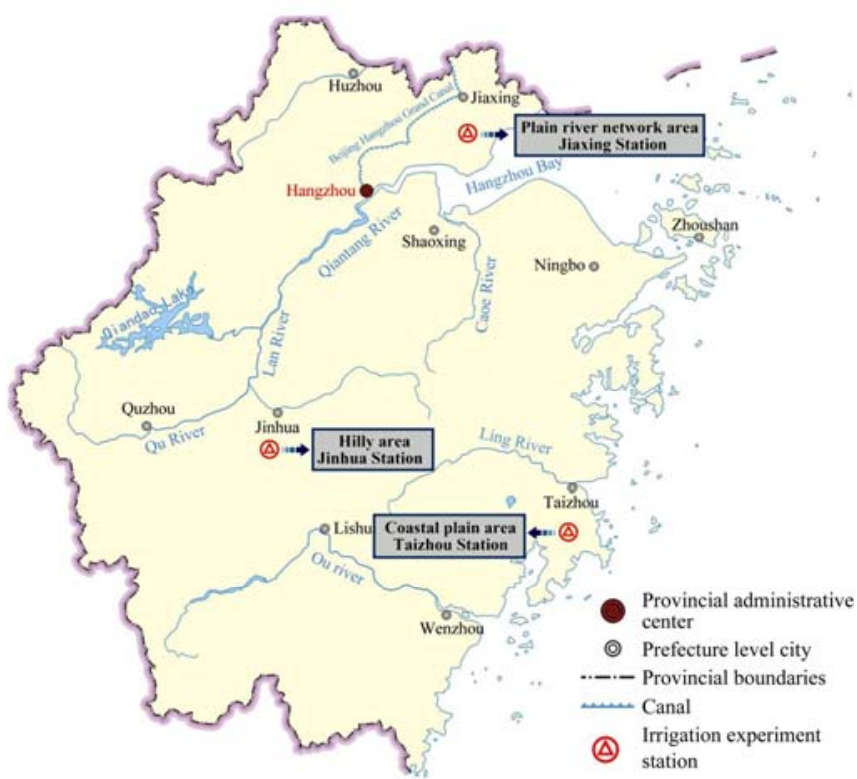

Figure 1 Locations of experiment stations of three different typical areas in Zhejiang Province

\subsection{Experimental design}

The whole growth stage of rice was divided into seven stages: soaking, re-greening, tillering, jointing-booting, heading-flowering, milking and ripening stage. For Yongkang experiment station, paddy rice (hybrid rice Zhongzheyou 1) was grown with 3 kinds of irrigation and drainage methods including conventional irrigation and drainage W0, two kinds of controlled irrigation and drainage (W1-H: intermittent irrigation, and W2-H: rainfall storage-intermittent irrigation). As for Jinqing experiment station, paddy rice (hybrid rice Yongyou 1540) was grown with 3 kinds of irrigation and drainage methods including conventional irrigation and drainage W0, two kinds of controlled irrigation and drainage (W1-CP: rain storage-thin dew irrigation, and W2-CP: high rainfall storage irrigation). And for Pinghu experiment station, paddy rice (conventional single cropping rice Xiushui 12) was grown with 3 kinds of irrigation and drainage methods including conventional irrigation and drainage W0, 2 kinds of controlled irrigation and drainage (W1-PR: thin dew irrigation, W2-PR: same as W2-CP). Water level controls are listed in Table 1.

Two fertilization methods were set for each typical area, namely, two times of fertilization (F2) and three times of fertilization (F3). F2 was applied with base fertilizer and tillering fertilizer, and the fertilization time was before tillering stage and during tillering stage respectively. F3 was applied with base fertilizer, tillering fertilizer and panicle fertilizer, and the fertilization time was before tillering stage, during tillering stage and before heading and flowering stage respectively. Fertilizer varieties and amounts in different typical areas are listed in Table 2. 
Table 1 Water level control in paddy field for different irrigation methods ( $\mathbf{m m})$

\begin{tabular}{|c|c|c|c|c|c|c|c|c|}
\hline IM & WLC & RG & ETL & LTL & JB & $\mathrm{HF}$ & ML & $\mathrm{RP}$ \\
\hline \multirow[b]{2}{*}{ W0 } & Lower limit & 20 & 20 & 30 & 30 & 10 & 10 & 0 \\
\hline & Upper limit & 30 & 50 & 60 & 60 & 50 & 50 & 0 \\
\hline \multirow{3}{*}{ W1-H } & Lower limit & 0 & Exposing field $3-5 \mathrm{~d}$ & Exposing field 7-12 d & Exposing field 2-4 d & Exposing field 2-4 d & Exposing field 3-5 d & \multirow{3}{*}{ Fall dry } \\
\hline & Upper limit & 30 & 30 & Field dry & 40 & 40 & 30 & \\
\hline & Rain storage & 40 & 50 & Field dry & 60 & 60 & 60 & \\
\hline \multirow{3}{*}{ W2-H } & Lower limit & 0 & Exposing field $3-5 \mathrm{~d}$ & Exposing field 7-14 d & Exposing field 1-3 d & Exposing field $1-3 \mathrm{~d}$ & Exposing field 3-5 d & \multirow{3}{*}{ Fall dry } \\
\hline & Upper limit & 30 & 30 & Field dry & 40 & 40 & 30 & \\
\hline & Rain storage & 50 & 70 & 20 & 120 & 100 & 60 & \\
\hline \multirow{3}{*}{ W1-CP } & Lower limit & 5 & $0.8 \theta_{S}$ & $0.7 \theta_{S}$ & $0.9 \theta_{S}$ & 0 & $0.8 \theta_{S}$ & \\
\hline & Upper limit & 30 & 20 & 20 & 30 & 30 & 20 & \\
\hline & Rain storage & 50 & 80 & 0 & 140 & 120 & 80 & \\
\hline \multirow{2}{*}{ W2-CP } & Lower limit & Soil wet & $0.7 \theta_{S}$ & $0.6 \theta_{S}$ & $0.75 \theta_{S}$ & $0.8 \theta_{S}$ & $0.7 \theta_{S}$ & Fall dry \\
\hline & Rain storage & 50 & 100 & 150 & 200 & 200 & 100 & 50 \\
\hline \multirow{3}{*}{ W1-PR } & Lower limit & 5 & $0.8 \theta_{S}$ & $0.7 \theta_{S}$ & $0.9 \theta_{S}$ & 0 & $0.8 \theta_{S}$ & \multirow{3}{*}{ Fall dry } \\
\hline & Upper limit & 30 & 20 & 20 & 30 & 30 & 20 & \\
\hline & Rain storage & 40 & 50 & 0 & 60 & 60 & 30 & \\
\hline
\end{tabular}

W2-PR Water level control is the same as W2-CP

Note: IM and WLC represented irrigation method and water level control; RG, ETL, LTL, JB, HF, ML and RP represented the growth stage of re-greening, early tillering, late tillering, jointing-booting, heading-flowering, milking, and ripening stage of paddy field; $\theta_{S}$ represented water holding capacity in paddy field. $\mathrm{H}$, $\mathrm{CP}$, and PR represent hilly area, coastal plain area and plain river network area, respectively.

Table 2 Fertilization methods and amount in different experimental areas

\begin{tabular}{|c|c|c|c|}
\hline Station & Fertilizer method & Fertilizer variety & Amount \\
\hline \multirow{4}{*}{$\begin{array}{l}\text { Hilly area } \\
\text { (Jinhua) }\end{array}$} & \multirow{2}{*}{$\mathrm{F} 2$} & Base fertilizer: compound fertilizer & $600 \mathrm{~kg} \cdot \mathrm{hm}^{-2}$ \\
\hline & & Tillering fertilizer: compound fertilizer & $600 \mathrm{~kg} \cdot \mathrm{hm}^{-2}$ \\
\hline & \multirow[t]{2}{*}{$\mathrm{F} 3$} & Tillering fertilizer: compound fertilizer & $360 \mathrm{~kg} \cdot \mathrm{hm}^{-2}$ \\
\hline & & Panicle fertilizer: compound fertilizer & $240 \mathrm{~kg} \cdot \mathrm{hm}^{-2}$ \\
\hline \multirow{4}{*}{$\begin{array}{l}\text { Coastal plain area } \\
\text { (Taizhou) }\end{array}$} & $\mathrm{F} 2$ & Base fertilizer: compound fertilizer and urea & $660 \mathrm{~kg} \cdot \mathrm{hm}^{-2}$ compound fertilizer and $30 \mathrm{~kg} \cdot \mathrm{hm}^{-2}$ urea \\
\hline & \multirow{3}{*}{ F3 } & Base fertilizer: compound fertilizer and urea & $660 \mathrm{~kg} \cdot \mathrm{hm}^{-2}$ compound fertilizer and $30 \mathrm{~kg} \cdot \mathrm{hm}^{-2}$ urea \\
\hline & & Tillering fertilizer: urea & $150 \mathrm{~kg} \cdot \mathrm{hm}^{-2}$ \\
\hline & & Panicle fertilizer: urea & $100 \mathrm{~kg} \cdot \mathrm{hm}^{-2}$ \\
\hline \multirow{4}{*}{$\begin{array}{l}\text { Plain river network area } \\
\text { (Jiaxing) }\end{array}$} & \multirow{2}{*}{ F2 } & Base fertilizer: urea & $130 \mathrm{~kg} \cdot \mathrm{hm}^{-2}$ \\
\hline & & Tillering fertilizer: urea & $100 \mathrm{~kg} \cdot \mathrm{hm}^{-2}$ \\
\hline & \multirow{2}{*}{ F3 } & Base fertilizer: urea & $130 \mathrm{~kg} \cdot \mathrm{hm}^{-2}$ \\
\hline & & Panicle fertilizer: urea & $50 \mathrm{~kg} \cdot \mathrm{hm}^{-2}$ urea \\
\hline
\end{tabular}

Note: Compound fertilizer with N:P:K was 18:8:15, and the nitrogen content in urea was $47 \%$.

\subsection{Indicators and measurements}

Water consumption was measured by the change of water level in field surface according to the measuring needle when there has a water layer, while it was measured by soil water content change according to soil moisture analyzer at 8:00 a.m. every 3-5 d. Water leakage was measured by the leakage meter every day, and then the leakage amount was calculated according to the reading difference by the measuring needle before and after. The transpiration was the difference between water consumption and leakage. Irrigation quota was measured by water meter in entrance in each experimental plot. The total irrigation quota in the whole growth stage was the sum of irrigation quota in every growth stage. At the end of the growth period, 5 holes of rice plants were chosen for yield measurement. The yield was calculated by measuring the yield-related factors such as the thousand-grain weight, the number of grains per spike, and the number of effective spikes. Water use efficiency (WUE) was defined as yield per unit of water consumption and calculated from the ratio of yield to water consumption, WUE could be divided into three types, and they were $\mathrm{WUE}_{\mathrm{I}}, \mathrm{WUE}_{\mathrm{P}}$ and $\mathrm{WUE}_{\mathrm{ET}}$ when the water consumption represented irrigation water, rainfall and crop water consumption, respectively.

Leaf area index (LAI) was measured by LAI-2000 canopy analyzer. The canopy analyzer was placed between two rows of rice plants when measuring, and the probe was set in the north-south direction. The level of the tripod and the probe were ensured for each measurement. At each growth stage, three rice plants were selected randomly, then the root part was separated from the above-ground part and washed for measurement, main root length was measured by the rule. Dry matter accumulation (DMA) in above-ground part was measured by selecting three representative plants, and then the stems, leaves and spike were cleaned separately before being killed out in the drying cabinet at $105^{\circ} \mathrm{C}$ for $1 \mathrm{~h}$. After that, the rice plants were dried in an oven at $80^{\circ} \mathrm{C}$ to the constant weight, the rice plant biomass of each part was weighed by a balance.

Irrigation and drainage waters were sampled when there was an irrigation or drainage process, and leakage water was sampled 
once every growth stage by leakage meter. Total nitrogen (TN) in field surface water and ground water was measured by potassium per sulfate oxidation and ultraviolet spectrophotometry method. Total phosphorus (TP) was measured in unfiltered samples according to indophenol blue method. COD was measured by potassium dichromate method. $\mathrm{NH}_{4}{ }^{+}-\mathrm{N}$ was determined by the Nessler reagent spectrophotometry method. The $\mathrm{NO}_{3}{ }^{-} \mathrm{N}$ concentration was measured by ultraviolet spectrophotometry method. The detailed measurement methods of TN, TP, COD, $\mathrm{NO}_{3}{ }^{-}-\mathrm{N}$, and $\mathrm{NH}_{4}{ }^{+}-\mathrm{N}$ refer to [20].

\subsection{Statistical analysis}

Data calculation and diagramming were completed by Excel 2013. ANOVA analysis was carried out by SPSS Statistics 20. The path analysis method adopting SEM (structural equation model) was carried out by AMOS.

\section{Results and discussion}

\subsection{Daily water consumption}

Change of daily water consumption (DWC) of paddy rice at each growth stage in a typical area is shown in Figure 2. Under the same typical area, the change patterns for F2 or F3 were almost the same under the same water level control. Generally, DWC was about the same at the beginning and end of growth period, while it was lower for controlled irrigation and drainage (W1 and W2) than that for conventional irrigation (W0) during the other main growth periods. There was no significant difference between $\mathrm{W} 1$ and W2. It illustrated that field water conditions could be improved according to water-saving irrigation, which could effectively reduce field water consumption. For the hilly area, the peak of DWC was at the late tillering stage for W0 $(8.72 \mathrm{~mm})$, while it was at the jointing-booting stage for $\mathrm{W} 1-\mathrm{H}$ $(6.77 \mathrm{~mm})$ and $\mathrm{W} 2-\mathrm{H}(6.76 \mathrm{~mm})$, the peak value was 1.3 times for W1-H or W2-H than that for W0. For coastal plain area, the peak
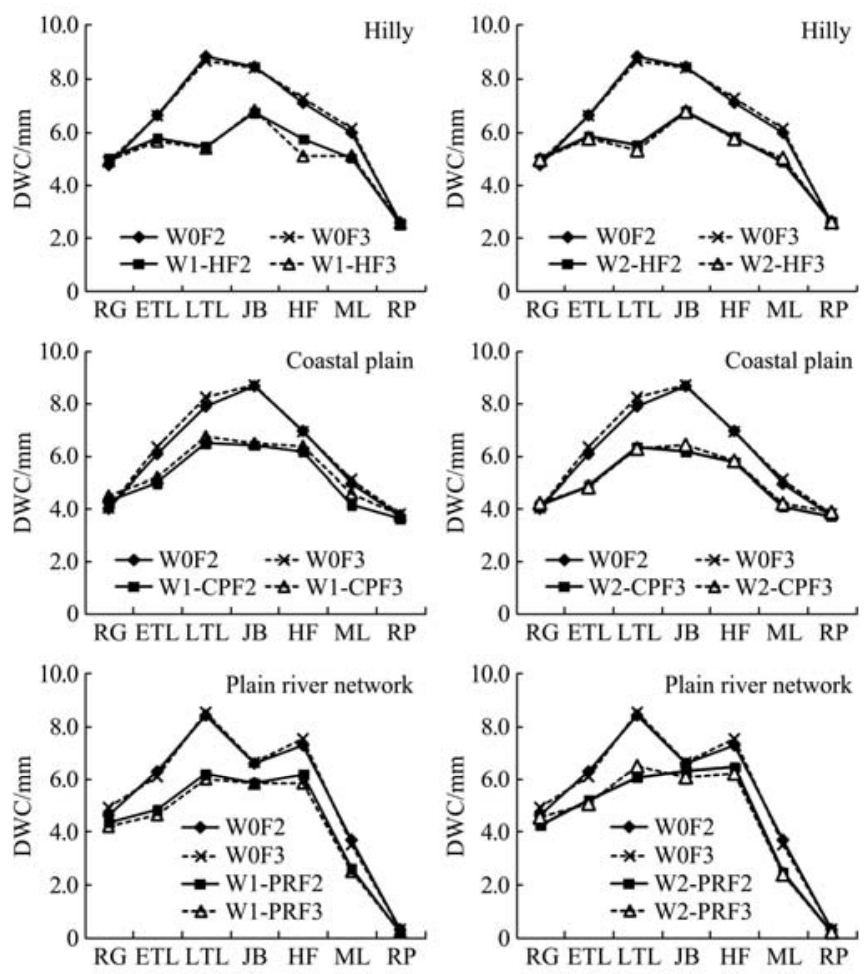

a. W0 and W1

b. W0 and W2

Figure 2 Changes of DWC of paddy rice at each growth stage in typical area of Zhejiang Province, China of DWC was at the jointing-booting stage for W0 $(8.67 \mathrm{~mm})$, while it was at later tillering stage for W1-CP $(6.43 \mathrm{~mm})$ and W2-CP $(6.28 \mathrm{~mm})$, the peak value was also about 1.3 times for W1-CP or W2-CP than that for W0. For plain river network area, there were 2 peak values for W0 $(8.47 \mathrm{~mm}$ and $7.39 \mathrm{~mm}), \mathrm{W} 1-\mathrm{PR}(6.07 \mathrm{~mm}$ and $6.83 \mathrm{~mm})$ and W2-PR $(6.25 \mathrm{~mm}$ and $5.98 \mathrm{~mm})$, respectively at the late tillering stage and heading-flowering stage, it was about 1.4 and 1.2 times for W1-PR or W2-PR than that for W0 at two peak points, respectively. It indicated that both rising and falling rates of W0 were greater than those of W1 and W2 at the three typical areas, and the values of DWC were at a relatively high level from late tillering stage to heading-flowering stage, which was mainly due to rice plant growing fast, and evaporation and transpiration were large during these periods. In addition, the DWC of different rice varieties varied greatly, which showed that the DWC of hybrid rice was higher than that of conventional single cropping rice.

\subsection{Irrigation quota}

Changes in irrigation quota during the whole growth period of rice in typical area are shown in Figure 3. Irrigation quota includes irrigation amount in soaking period and growing period. Irrigation quota in soaking period was mainly related to soil moisture, soaking time and climate, and it had no relationship to irrigation and fertilizer regulation, therefore it showed no significant change in the same typical area. The average irrigation quota in soaking period was $1008.9 \mathrm{~m}^{3} / \mathrm{hm}^{2}, 682.5 \mathrm{~m}^{3} / \mathrm{hm}^{2}$ and $566.75 \mathrm{~m}^{3} / \mathrm{hm}^{2}$ respectively for hilly area, coastal area and plain river network. It was shown that the irrigation quota in soaking period at hilly area was significantly higher than that at plain area, whether it was coastal plain area or plain river network area.

Irrigation quota in growing period was mainly affected by irrigation and drainage control in a paddy field, and it was higher for conventional irrigation (W0) than those for controlled irrigation and drainage (W1-H, W2-H, W1-CP, W2-CP, W1-PR and W2-PR) in the whole growth period of rice and the fertilizer application showed no regularity on irrigation quota. For the hilly area, the irrigation quota for W0 was $58.3 \%$ and $57.7 \%$ higher than that for $\mathrm{W} 1-\mathrm{H}$ and $\mathrm{W} 2-\mathrm{H}$. For coastal area, the irrigation quota for W0 was $37.0 \%$ and $52.8 \%$ higher than that for $\mathrm{W} 1-\mathrm{CP}$ and $\mathrm{W} 2-\mathrm{CP}$, while for plain river network area, it was $41.4 \%$ and $71.7 \%$ higher than that for W1-PR and W2-PR. Meanwhile, the difference between W1 (W1-CP and W1-PR) and W2 (W2-CP and W2-PR) was obviously significant at both coastal plain area and plain river network area. The main reason was that the water level regulation of W2-CP and W2-PR was the same, and the flood resistance of rice was used to the greatest extent, which greatly increased the upper limit of rain storage, and more rainfall was retained through the ridge in paddy field, which increased the rainfall use efficiency, so as to reduce the amount of irrigation water. Won examined the effects of very shallow intermittent irrigation (VSII, $2 \mathrm{~cm}$ ), shallow intermittent irrigation (SII, $4 \mathrm{~cm}$ ) and traditional deep water irrigation (DWI, $10 \mathrm{~cm}$ ) on rice growth, yield and water irrigation amount in the field for two years, the result showed that the water-saving rate was $32.9 \%$ in VSII and $17.2 \%$ in SII as compared with DWI, but the crop and yield were not significantly influenced in Korea ${ }^{[21]}$. The reason why the water-saving range was higher in our study than that of won's research results was that the field water level regulation was added to the upper limit of water level control and rain storage, so the rainfall use efficiency was improved and the irrigation water volume was greatly reduced. 

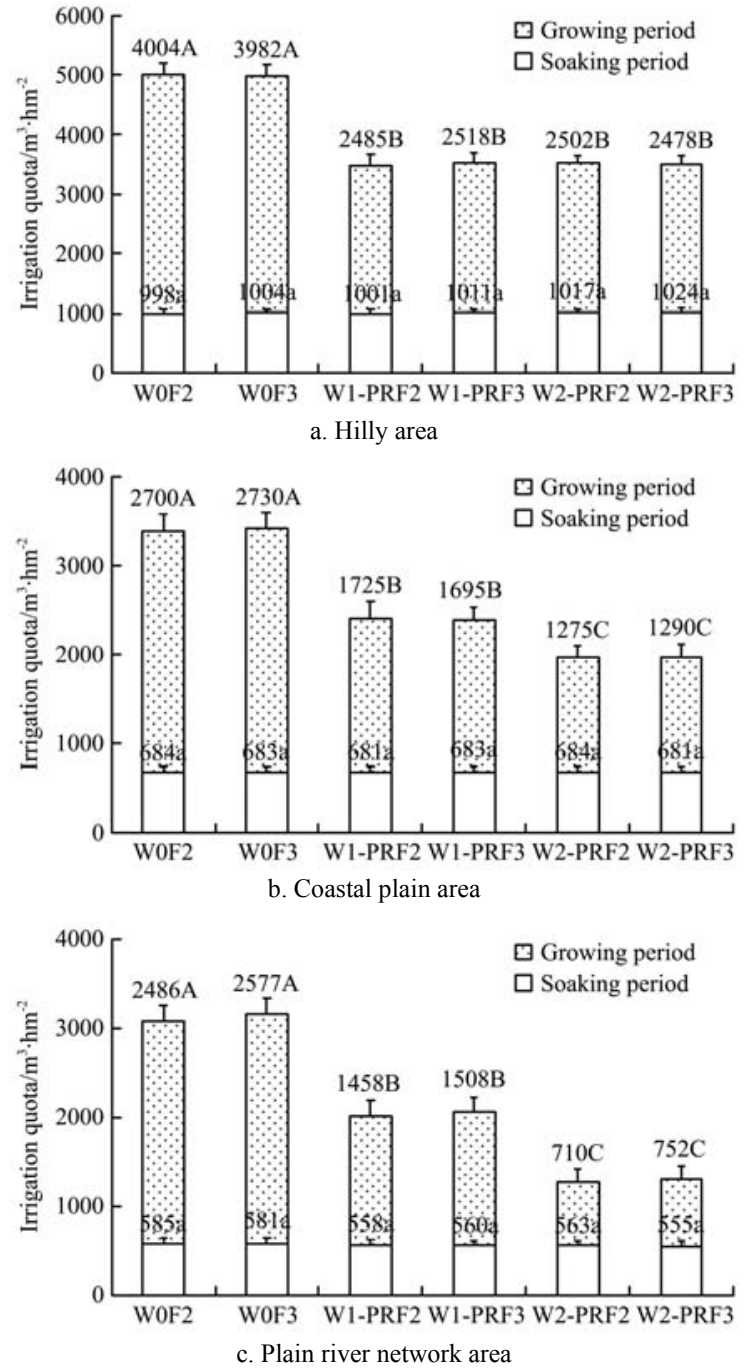

Figure 3 Change of irrigation quota during the whole growth period in typical area of Zhejiang Province, China

\subsection{Crop growth and yield}

Change of crop growth and yield during the whole growth period in typical areas are shown in Figure 4. In the same typical area, for hilly area, under W0, the average root length, DMA, LAI, and yield of rice were $287.5 \mathrm{~mm}, 262.9 \mathrm{~g}, 1.78$, and $9117.3 \mathrm{~kg} / \mathrm{hm}^{2}$, respectively, under $\mathrm{W} 1-\mathrm{H}$, they were $290.0 \mathrm{~mm}, 272.79 \mathrm{~g}, 1.87$ and $9304 \mathrm{~kg} / \mathrm{hm}^{2}$, respectively, under $\mathrm{W} 2-\mathrm{H}$, they were $307.5 \mathrm{~mm}$, $291.0 \mathrm{~g}, 1.91$ and $9310.5 \mathrm{~kg} / \mathrm{hm}^{2}$, respectively. For coastal plain area, under W0, they were $290 \mathrm{~mm}, 335.5 \mathrm{~g}, 1.85$ and $11086.5 \mathrm{~kg} / \mathrm{hm}^{2}$, respectively, under $\mathrm{W} 1-\mathrm{CP}$, they were $295 \mathrm{~mm}, 332 \mathrm{~g}, 1.93$, and $10941.0 \mathrm{~kg} / \mathrm{hm}^{2}$, respectively, under W2-CP, they were $320 \mathrm{~mm}$, $341 \mathrm{~g}, 1.94$ and $11328.8 \mathrm{~kg} / \mathrm{hm}^{2}$, respectively. For plain river network area, under W0, they were $266.0 \mathrm{~mm}, 189.1 \mathrm{~g}, 1.45$, and $8064.8 \mathrm{~kg} / \mathrm{hm}^{2}$, respectively, under W1-PR, they were $270 \mathrm{~mm}$, $208.9 \mathrm{~g}, 1.55$, and $8206.5 \mathrm{~kg} / \mathrm{hm}^{2}$, respectively, under W2-PR, and they were $274.5 \mathrm{~mm}, 216.7 \mathrm{~g}, 1.57$, and $8123.3 \mathrm{~kg} / \mathrm{hm}^{2}$, respectively. It can be seen that the growth indicators and yield of rice under controlled irrigation and drainage (W1 and W2) were significantly higher than those under conventional irrigation and drainage (W0). W1 and W2 were basically the same, and the difference was not obvious. Compared with W0, the average increase in the range of root length, DMA, LAI, and yield under W1 or W2 were $2.3 \%-4.0 \%, 0.3 \%-12.5 \%, 4.4 \%-7.4 \%$, and $0.4 \%$ $2.1 \%$, respectively, The crop growth indicators and yield of F3 were slightly higher than that of F2, indicating that decentralized fertilization was more conducive to rice growth. Le found that alternate wetting and drying water management was effective and could conserve water, and rice yield can be maintained by achieving a maximum drying index ${ }^{[22]}$, which was consistent with our study.

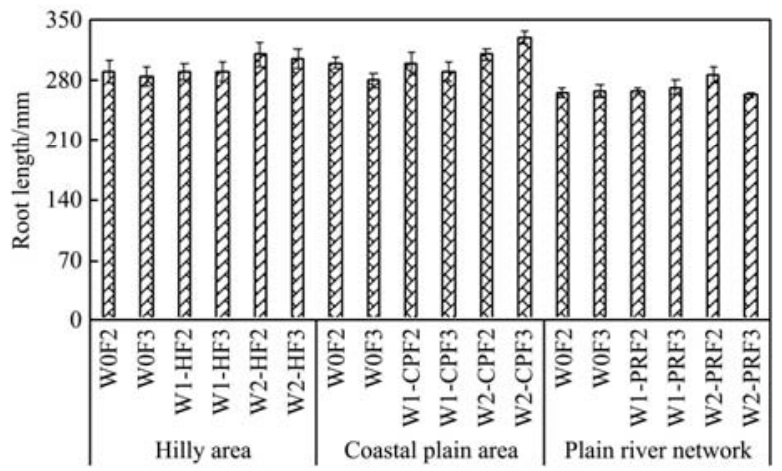

a. Root length

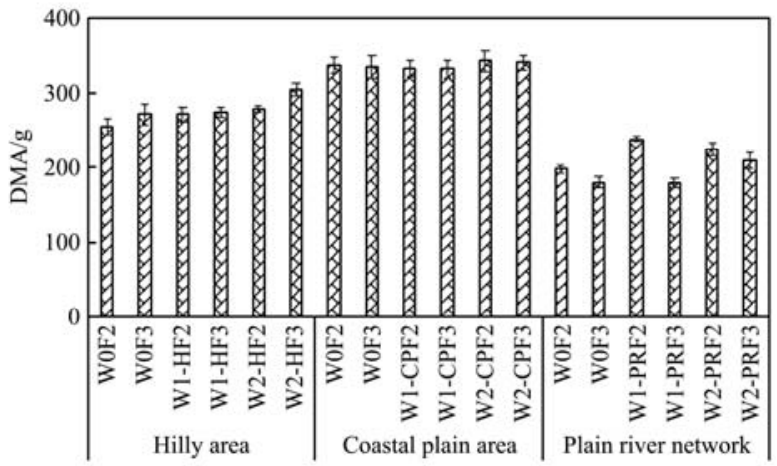

b. DMC

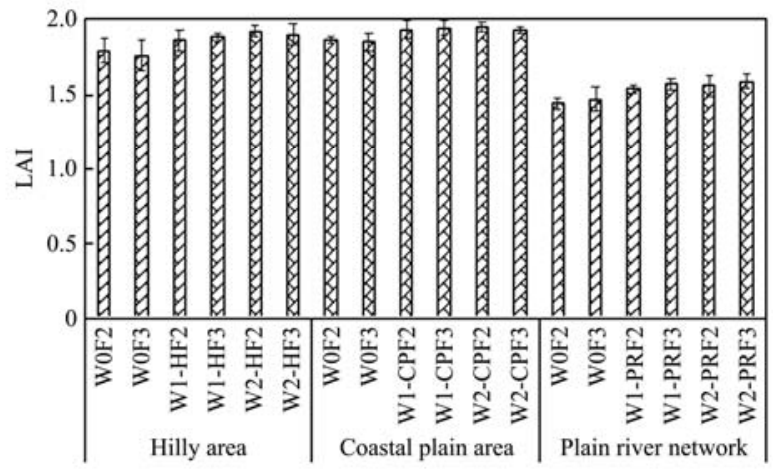

c. LAI

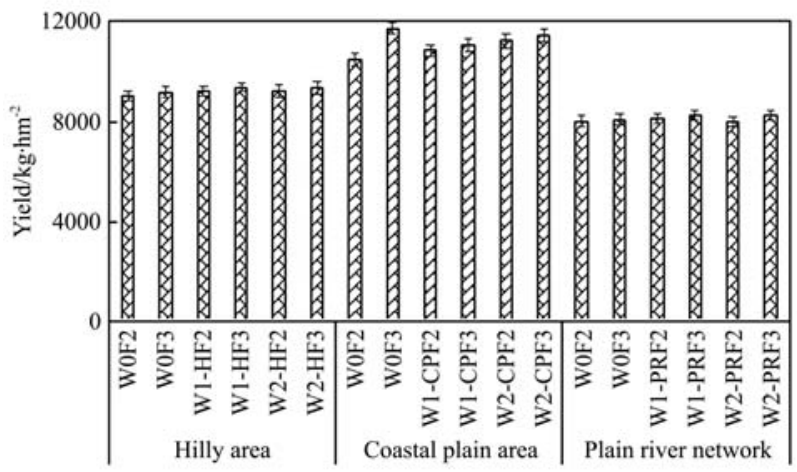

d. Yield

Figure 4 Changes of crop growth and yield during the whole growth period in typical area of Zhejiang Province, China

In different typical areas, for hilly area, the average root length, DMA, LAI, and yield of rice were $295.0 \mathrm{~mm}, 275.6 \mathrm{~g}, 1.85$, and $9243.9 \mathrm{~kg} / \mathrm{hm}^{2}$, respectively, for coastal plain area, they were $301.7 \mathrm{~mm}, 336.2 \mathrm{~g}, 1.91$, and $11118.6 \mathrm{~kg} / \mathrm{hm}^{2}$, respectively, for 
plain river network area, they were $271.2 \mathrm{~mm}, 206.2 \mathrm{~g}, 1.54$, and $8150.7 \mathrm{~kg} / \mathrm{hm}^{2}$, respectively. It showed that the growth and yield of crops in hilly area were close to those in coastal plain area, but they were much higher than those in plain river network area. It was because the rice varieties in hilly area and plain river network areas were hybrid rice, while it was conventional single cropping rice in plain river network. Yuan found that the growth characteristics and absorption and transformation capacity of different rice varieties were quite different, Among them, the yield potential of hybrid rice was generally $10 \%-20 \%$ higher than that of conventional rice, and the nitrogen uptake capacity was higher than that of conventional rice ${ }^{[23]}$. It was basically consistent with the changes in yield and growth characteristics in this paper.

\subsection{Water demand and water use efficiency}

Change of water demand and water use efficiency (WUE) in typical areas is listed in Table 3. Generally, in a typical area, the water demand of leakage, evapotranspiration, and water consumption under controlled irrigation and drainage (W1 and W2) was obviously lower than that under conventional irrigation and drainage (W0), but rainfall utilization rate was the opposite, and the water demand showed no significance between W1 and W2, basically. As for different fertilizer times, it showed no significance between F2 and F3, basically, therefore, it was only analyzed under different water level regulations. For hilly area, compared to W0, the leakage, evapotranspiration, water consumption and rainfall utilization rate was $40.31 \%, 19.09 \%$, $19.95 \%$ lower, but $8.20 \%$ higher than that of $\mathrm{W} 1-\mathrm{H}$, and it was $39.97 \%, 18.68 \%, 19.55 \%$ lower, but $9.84 \%$ higher than that of W2-H. For coastal plain area, compared to W0, it was $54.64 \%$, $2.58 \%, 6.91 \%$ lower, but $19.51 \%$ higher than that of W1-CP, and it was $60.80 \%, 1.52 \%, 6.63 \%$ lower, but $43.90 \%$ higher than that of W2-CP. For plain river network area, compared to W0, it was $58.53 \%, 31.53 \%, 34.40 \%$ lower, but $30.99 \%$ higher than that of W1-PR, and it was $50.84 \%, 9.40 \%, 13.82 \%$ lower, but $129.58 \%$ higher than that of W2-PR. In different typical areas, evapotranspiration and water consumption was $27.73 \%$ and $24.20 \%$ larger in hilly area (hybrid rice), $29.47 \%$ and $27.97 \%$ larger in coastal plain (hybrid rice) than that of plain river network (conventional single cropping rice), and the difference was mainly caused by the difference of rice varieties.

Table 3 Change of water demand and water use efficiency in typical area in Zhejiang Province, China

\begin{tabular}{|c|c|c|c|c|c|c|c|c|}
\hline \multirow{2}{*}{$\begin{array}{l}\text { Typical } \\
\text { area }\end{array}$} & \multirow{2}{*}{ Treatment } & \multicolumn{4}{|c|}{ Water demand $/ \mathrm{mm}$} & \multicolumn{3}{|c|}{$\mathrm{WUE} / \mathrm{kg} \cdot \mathrm{m}^{-3}$} \\
\hline & & Leakage & Evapotrans-piration & Water consumption & Rainfall use rate $/ \%$ & WUE $_{I}$ & WUEP $_{\mathrm{P}}$ & WUE $E_{\mathrm{ET}}$ \\
\hline \multirow{5}{*}{ Hilly area } & W0F2 & $27.0 \pm 1.24^{\mathrm{a}}$ & $649.9 \pm 6.06^{\mathrm{a}}$ & $676.9 \pm 6.18^{\mathrm{a}}$ & $61 \pm 3.46^{\mathrm{a}}$ & $2.1 \pm 0.03^{\mathrm{ab}}$ & $3.8 \pm 0.02^{\mathrm{a}}$ & $1.3 \pm 0.04^{b}$ \\
\hline & W0F3 & $30.8 \pm 1.07^{\mathrm{a}}$ & $646.9 \pm 6.32^{\mathrm{a}}$ & $677 \pm 6.29^{\mathrm{a}}$ & $61 \pm 3.46^{\mathrm{a}}$ & $2.1 \pm 0.03^{\mathrm{ab}}$ & $3.9 \pm 0.03^{\mathrm{a}}$ & $1.4 \pm 0.03^{\mathrm{b}}$ \\
\hline & W1-HF2 & $17.3 \pm 0.93^{\mathrm{b}}$ & $522.3 \pm 4.99^{\mathrm{b}}$ & $539.6 \pm 4.98^{\mathrm{b}}$ & $66 \pm 3.32^{\mathrm{a}}$ & $3.2 \pm 0.05^{\mathrm{a}}$ & $3.5 \pm 0.06^{\mathrm{a}}$ & $1.7 \pm 0.06^{\mathrm{a}}$ \\
\hline & W1-HF3 & $17.2 \pm 1.17^{\mathrm{b}}$ & $527.0 \pm 5.06^{\mathrm{b}}$ & $544.2 \pm 4.59^{\mathrm{b}}$ & $66 \pm 3.46^{\mathrm{a}}$ & $3.2 \pm 0.05^{\mathrm{a}}$ & $3.6 \pm 0.12^{\mathrm{a}}$ & $1.8 \pm 0.05^{\mathrm{a}}$ \\
\hline & W2-HF3 & $17.9 \pm 1.11^{\mathrm{b}}$ & $524.5 \pm 5.03^{\mathrm{b}}$ & $542.4 \pm 4.89^{\mathrm{b}}$ & $67 \pm 3.46^{\mathrm{a}}$ & $3.2 \pm 0.05^{\mathrm{a}}$ & $3.5 \pm 0.08^{\mathrm{a}}$ & $1.7 \pm 0.05^{\mathrm{a}}$ \\
\hline \multirow{6}{*}{$\begin{array}{c}\text { Coastal plain } \\
\text { area }\end{array}$} & W0F2 & $60.0 \pm 1.73^{\mathrm{a}}$ & $578.2 \pm 7.84^{\mathrm{c}}$ & $638 . \pm 6.71^{\mathrm{a}}$ & $43 \pm 1.73^{c}$ & $1.9 \pm 0.06^{\mathrm{c}}$ & $2.6 \pm 0.06^{\mathrm{b}}$ & $1.1 \pm 0.03^{\mathrm{c}}$ \\
\hline & W0F3 & $52.0 \pm 1.15^{\mathrm{b}}$ & $609.1 \pm 5.25^{\mathrm{a}}$ & $661.1 \pm 11.55^{\mathrm{a}}$ & $39 \pm 2.31^{\mathrm{c}}$ & $1.9 \pm 0.03^{\mathrm{c}}$ & $3.1 \pm 0.04^{\mathrm{a}}$ & $1.2 \pm 0.01^{\mathrm{b}}$ \\
\hline & W1-CPF2 & $27.3 \pm 0.49^{\mathrm{c}}$ & $564.0 \pm 2.31^{\mathrm{cd}}$ & $593.3 \pm 7.50^{\mathrm{c}}$ & $46 \pm 0.58^{b}$ & $2.5 \pm 0.0^{6 \mathrm{~b}}$ & $2.4 \pm 0.05^{\mathrm{c}}$ & $1.2 \pm 0.03^{\mathrm{b}}$ \\
\hline & W1-CPF3 & $23.5 \pm 0.29^{\mathrm{d}}$ & $592.7 \pm 5.78^{b}$ & $616.2 \pm 3.46 b^{c}$ & $50 \pm 0.58^{b}$ & $2.5 \pm 0.02^{\mathrm{b}}$ & $2.3 \pm 0.02^{\mathrm{cd}}$ & $1.2 \pm 0.01^{\mathrm{b}}$ \\
\hline & W2-CPF2 & $24.1 \pm 0.15^{\mathrm{d}}$ & $560.0 \pm 3.46^{\mathrm{d}}$ & $584.1 \pm 2.31^{\mathrm{c}}$ & $58 \pm 1.15^{\mathrm{a}}$ & $3.1 \pm 0.05^{\mathrm{a}}$ & $2.2 \pm 0.04^{\mathrm{d}}$ & $1.3 \pm 0.01^{\mathrm{a}}$ \\
\hline & W2-CPF3 & $19.8 \pm 0.12^{\mathrm{e}}$ & $609.3 \pm 2.31^{\mathrm{a}}$ & $629.1 \pm 8.66^{\mathrm{b}}$ & $60 \pm 0.88^{\mathrm{a}}$ & $3.0 \pm 0.02^{\mathrm{a}}$ & $2.3 \pm 0.03^{\mathrm{cd}}$ & $1.3 \pm 0.02^{\mathrm{a}}$ \\
\hline \multirow{5}{*}{$\begin{array}{c}\text { Plain river } \\
\text { network area }\end{array}$} & W0F3 & $56.6 \pm 1.13^{\mathrm{a}}$ & $480.6 \pm 6.35^{\mathrm{a}}$ & $537.2 \pm 4.33^{\mathrm{a}}$ & $36 \pm 0.42^{\mathrm{d}}$ & $3.1 \pm 0.03^{\mathrm{d}}$ & $4.1 \pm 0.07^{\mathrm{c}}$ & $1.8 \pm 0.03^{\mathrm{c}}$ \\
\hline & W1-PF2 & $21.5 \pm 0.29^{\mathrm{d}}$ & $321.7 \pm 3.46^{\mathrm{c}}$ & $343.2 \pm 5.55^{\mathrm{c}}$ & $45 \pm 0.73^{\mathrm{c}}$ & $5.2 \pm 0.06^{\mathrm{c}}$ & $4.5 \pm 0.10^{\mathrm{b}}$ & $2.4 \pm 0.03^{\mathrm{a}}$ \\
\hline & W1-PF3 & $25.4 \pm 0.4^{\mathrm{c}}$ & $327.9 \pm 3.06^{\mathrm{c}}$ & $353.3 \pm 4.04^{\mathrm{c}}$ & $48 \pm 0.64^{\mathrm{b}}$ & $5.5 \pm 0.04^{\mathrm{b}}$ & $4.8 \pm 0.05^{\mathrm{a}}$ & $2.5 \pm 0.06^{\mathrm{a}}$ \\
\hline & W2-PF2 & $26.8 \pm 0.61^{\mathrm{bc}}$ & $425.3 \pm 6.96^{\mathrm{b}}$ & $452.1 \pm 4.91^{\mathrm{b}}$ & $82 \pm 0.58^{\mathrm{a}}$ & $9.3 \pm 0.08^{\mathrm{a}}$ & $2.5 \pm 0.03^{\mathrm{e}}$ & $2.0 \pm 0.04^{\mathrm{b}}$ \\
\hline & W2-CPF3 & $28.8 \pm 0.69^{\mathrm{b}}$ & $434.2 \pm 5.48^{b}$ & $463.0 \pm 2.60^{\mathrm{b}}$ & $81 \pm 0.46^{\mathrm{a}}$ & $9.4 \pm 0.12^{\mathrm{a}}$ & $2.7 \pm 0.04^{\mathrm{f}}$ & $2.1 \pm 0.03^{b}$ \\
\hline
\end{tabular}

WUE could directly reflect the economic benefits of water resources. In a typical area, $\mathrm{WUE}_{\mathrm{I}}$, and $\mathrm{WUE}_{\mathrm{ET}}$ for $\mathrm{W} 1$ and $\mathrm{W} 2$ were higher, but $\mathrm{WUE}_{\mathrm{P}}$ was lower than that of W0, obviously, and WUE showed obvious significance in coastal plain area and plain river network area, but no significance in hilly area between W1 and W2. As for different fertilizer methods, it showed no significance between F2 and F3, basically. For hilly area, compared to $\mathrm{W} 0, \mathrm{WUE}_{\mathrm{I}}, \mathrm{WUE}_{\mathrm{ET}}$, and $\mathrm{WUE}_{\mathrm{P}}$ was $52.38 \%, 29.63 \%$ higher and $7.79 \%$ lower than that of $\mathrm{W} 1-\mathrm{H}$, while $50.0 \%, 25.93 \%$ higher and $10.39 \%$ lower than that of W2-H. For coastal area, it was $31.58 \%, 4.35 \%$ higher and $17.54 \%$ lower than that of W1-CP, while $60.53 \%, 13.04 \%$ higher and $21.95 \%$ lower than that of W2-CP. For plain river network area, it was $72.58 \%, 40.00 \%$ higher and $17.72 \%$ lower than that of W1-PR, while $201.61 \%$, $17.14 \%$ higher and $34.18 \%$ lower than that of W2-PR. In different typical areas, the difference in WUE was mainly caused by the difference in rice varieties.

The analysis above indicated that water consumption of rice was affected mainly by irrigation methods and rice varieties. As for W1 and W2, the water layer of paddy field was effectively controlled, resulting in wet and dry alternation for rice plants. While ensuring the physiological water demand (evapotranspiration) of rice and ecological water demand of rice fields, the field surface evaporation was reduced, therefore the water consumption could be significantly reduced, at the same time, the evapotranspiration of hybrid rice was obviously higher than that of conventional single cropping rice. $\mathrm{WUE}_{\mathrm{I}}$ was affected by yield and irrigation amount, and it was obviously higher for W1 and W2 than that for W0, and $\mathrm{WUE}_{\mathrm{P}}$ was affected by yield and rain storage, W1 and W2 had no significant difference because of rain storage in hilly area, however, they were obvious significant in coastal plain area and plain river network area, that was the reason obvious significance of WUE in coastal plain area and plain river network area. Rice water demand is an important part of rice field water balance and an important link in the study of water cycle, and the law of rice water demand is the dynamic demand characteristics of rice for water in the growth process ${ }^{[24]}$. Peng found that compared with the shallow wet irrigation and field groundwater depth control, the 
water demand under the controlled irrigation and suitable groundwater depth model was reduced by $25.3 \%$, and the water demand under the controlled irrigation and controlled groundwater depth model was reduced by $34.4 \%{ }^{[25]}$. In our study, compared to W0, water demand of evapotranspiration was decreased by $9.40 \%$ $31.53 \%$ under $\mathrm{W} 1$ and $\mathrm{W} 2$, which was basically consistent with Peng's results.

\subsection{Non-point source pollution reduction}

The dynamics of pollution reduction in paddy field is shown in Figure 5, and the total reduction of pollution load is listed in Table 4. Generally, the reduction of non-point source pollution occurred mainly in surface water. It was clear that nitrogen was the main pollution in surface water and groundwater, while phosphorus account for a lower proportion. $\mathrm{NH}_{4}{ }^{+} \mathrm{N}$ reduction was higher than $\mathrm{NO}_{3}{ }^{-}-\mathrm{N}$. The pollutant nitrogen reduction in surface water was mainly $\mathrm{NH}_{4}{ }^{+}-\mathrm{N}$, and the nitrogen reduction in groundwater was mainly $\mathrm{NO}_{3}{ }^{-}-\mathrm{N}$. The reduction of $\mathrm{TN}, \mathrm{NO}_{3}{ }^{-}-\mathrm{N}, \mathrm{NH}_{4}{ }^{+}-\mathrm{N}$, and COD for controlled irrigation and drainage (W1-H, W2-H, W1-CP, W2-CP, W1-PR, and W2-PR) was lower than that for W0. For the hilly area, compared to $\mathrm{W} 0$, the $\mathrm{TN}, \mathrm{NO}_{3}{ }^{-} \mathrm{N}, \mathrm{NH}_{4}{ }^{+}-\mathrm{N}$, and COD loss was $21.5 \%, 23.4 \%, 27.6 \%$, and $21.4 \%$ lower under W1-H, respectively, while it was $38.8 \%, 42.3 \%, 43.4 \%$, and $28.8 \%$ under W2-H. Compared to W1-H, TN, $\mathrm{NO}_{3}{ }^{-}-\mathrm{N}, \mathrm{NH}_{4}{ }^{+}-\mathrm{N}$ loss can be significantly reduced under $\mathrm{W} 2-\mathrm{H}$. For the coastal plain area, compared to W0, TN, $\mathrm{NO}_{3}{ }^{-}-\mathrm{N}, \mathrm{NH}_{4}{ }^{+}-\mathrm{N}$, and $\mathrm{COD}$ reduction was $20.0 \%, 21.8 \%, 21.5 \%$, and $31.2 \%$ under $\mathrm{W} 1-\mathrm{CP}$, while it was $27.3 \%, 22.6 \%, 22.8 \%$, and $33.6 \% \mathrm{~W} 2-\mathrm{CP}$. Different from the hilly area, W1-CP and W2-CP had no significant effect on reducing pollutants. For the plain river network area, compared to W0, the $\mathrm{TN}, \mathrm{NO}_{3}{ }^{-}-\mathrm{N}, \mathrm{NH}_{4}{ }^{+}-\mathrm{N}$, and $\mathrm{COD}$ reduction was $19.0 \%, 51.3 \%$, $30.8 \%$, and $44.3 \%$ lower under W1-PR, respectively, while it was $63.4 \%, 66.3 \%, 63.8 \%$ and $46.5 \%$ under W2-PR, and W2 decreased significantly higher than W1. Except for the coastal plain, TP reduction showed a descending trend under $\mathrm{W} 0, \mathrm{~W} 1$, and $\mathrm{W} 2$. The pollution reduction under W2 (W2-H, W2-CP, and W2-PR) was lower than that under W1 (W1-H, W1-CP, and W1-PR), which was mainly due to the increasing depth and duration of water storage after the rain for W2, which was favorable for nitrogen absorption by plant and nitrogen fixation by soil. With the comparison to $\mathrm{F} 2$, the pollution reduction was relatively lower under F3, however, the differences between them were not significant for most pollution indicators, which was consistent with the theory that dispersed fertilization is beneficial to increase the absorption and utilization of nitrogen fertilizer. Therefore, fertilizer amount and method had a greater impact on the pollutant transport from paddy fields.

According to the analysis on the contribution of surface drainage and groundwater seepage to the reduction of various non-point source pollutants in paddy fields, it was found that TP, $\mathrm{TN}, \mathrm{NO}_{3}{ }^{-} \mathrm{N}, \mathrm{NH}_{4}{ }^{+} \mathrm{N}$ and COD reduction in field surface drainage accounted for $99.2 \%, 80.2 \%, 74.7 \%, 91.0 \%$ and $76.5 \%$ at hilly area, $89.3 \%, 69.6 \%, 22.8 \%, 83.4 \%$ and $89.1 \%$ at coastal plain area, $92.5 \%, 84.1 \%, 75.3 \%, 83.2 \%$ and $83.0 \%$ at plain river network area, respectively. This result was slightly different from Xiao ${ }^{[8,26]}$, which found the declining degree of nitrogen and phosphorus was higher compared to the results in this article. This was mainly because drainage occurs when the rain storage limit was 150 $200 \mathrm{~mm}$ without precipitation, thus the surface drainage and groundwater seepage were effectively controlled. While in this article, with consideration of precipitation, the drainage criterion (50-120 $\mathrm{mm})$ in each growth period was significantly lower.
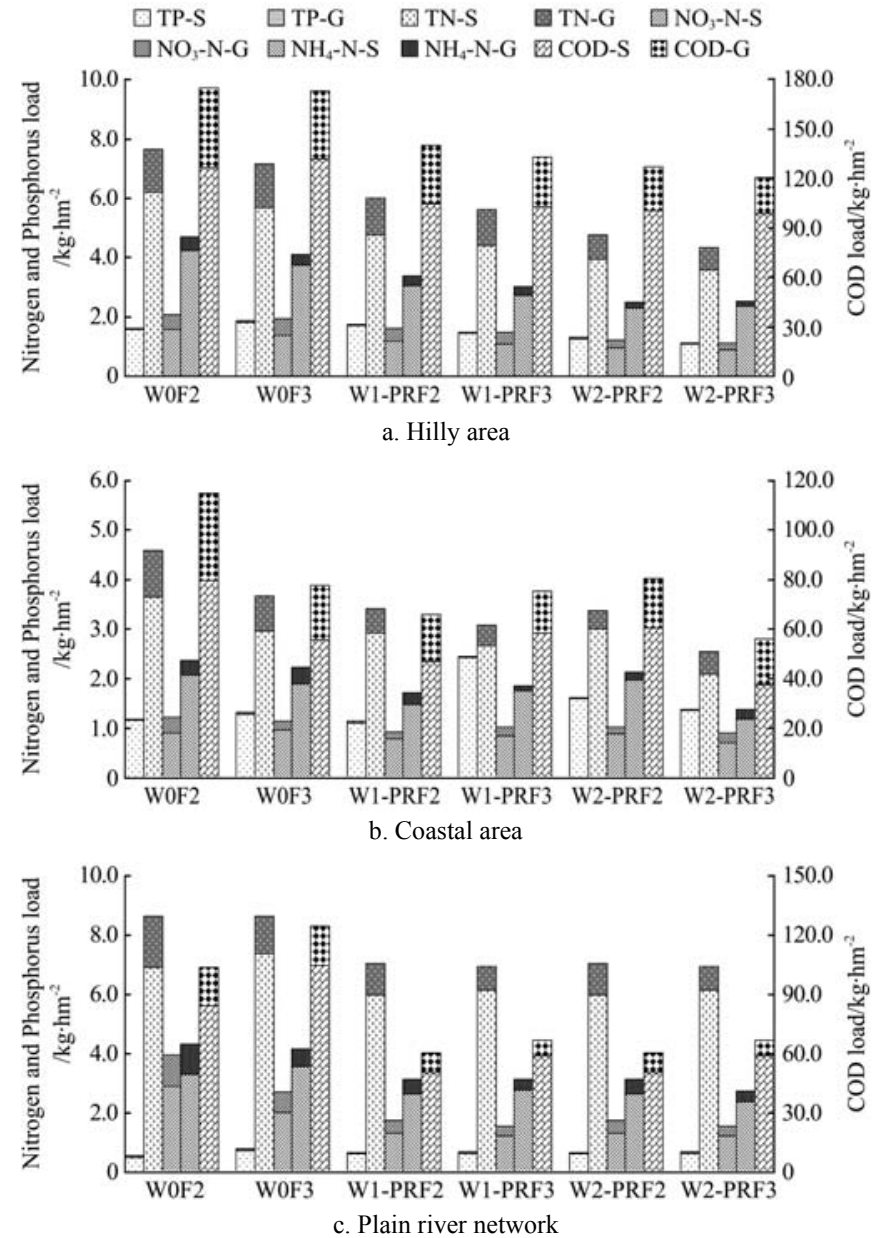

Note: S represented field surface drainage; G represented groundwater seepage.

Figure 5 Pollution reduction under water and fertilizer regulations in typical areas of Zhejiang Province, China

Table 4 Total reduction of pollution in the field under different water and fertilizer regulations in typical areas of Zhejiang Province, China

\begin{tabular}{|c|c|c|c|c|c|c|}
\hline $\begin{array}{c}\text { Typical } \\
\text { area }\end{array}$ & Treatment & $\begin{array}{c}\mathrm{TP} / \\
\mathrm{kg} \cdot \mathrm{hm}^{-2}\end{array}$ & $\begin{array}{c}\mathrm{TN} / \\
\mathrm{kg} \cdot \mathrm{hm}^{-2}\end{array}$ & $\begin{array}{l}\mathrm{NO}_{3}{ }^{-}-\mathrm{N} / \\
\mathrm{kg} \cdot \mathrm{hm}^{-2}\end{array}$ & $\begin{array}{l}\mathrm{NH}_{4}^{+}-\mathrm{N} / \\
\mathrm{kg} \cdot \mathrm{hm}^{-2}\end{array}$ & $\begin{array}{c}\mathrm{COD} / \\
\mathrm{kg} \cdot \mathrm{hm}^{-2}\end{array}$ \\
\hline \multirow{5}{*}{ Hilly area } & W0 & $1.71^{\mathrm{a}}$ & $7.40^{\mathrm{a}}$ & $2.01^{\mathrm{a}}$ & $4.38^{\mathrm{a}}$ & $173.78^{a}$ \\
\hline & W1-H & $1.58^{\mathrm{b}}$ & $5.81^{\mathrm{b}}$ & $1.54^{\mathrm{b}}$ & $3.17^{\mathrm{b}}$ & $136.58^{\mathrm{b}}$ \\
\hline & W2-H & $1.18^{\mathrm{c}}$ & $4.53^{\mathrm{c}}$ & $1.16^{\mathrm{c}}$ & $2.48^{\mathrm{b}}$ & $123.81^{\mathrm{b}}$ \\
\hline & F2 & $1.52^{\mathrm{a}}$ & $6.14^{\mathrm{a}}$ & $1.63^{\mathrm{a}}$ & $3.50^{\mathrm{a}}$ & $147.29^{\mathrm{a}}$ \\
\hline & F3 & $1.46^{\mathrm{a}}$ & $5.69^{\mathrm{b}}$ & $1.51^{\mathrm{a}}$ & $3.19^{\mathrm{a}}$ & $142.17^{\mathrm{a}}$ \\
\hline \multirow{5}{*}{$\begin{array}{l}\text { Coastal } \\
\text { plain area }\end{array}$} & W0 & $1.35^{\mathrm{b}}$ & $4.06^{\mathrm{a}}$ & $1.24^{\mathrm{a}}$ & $2.28^{\mathrm{a}}$ & $102.80^{\mathrm{a}}$ \\
\hline & W1-CP & $1.77^{\mathrm{a}}$ & $3.25^{\mathrm{b}}$ & $0.97^{\mathrm{b}}$ & $1.79^{\mathrm{b}}$ & $70.70^{\mathrm{b}}$ \\
\hline & W2-CP & $1.49^{\mathrm{b}}$ & $2.95^{\mathrm{b}}$ & $0.96^{\mathrm{b}}$ & $1.76^{\mathrm{b}}$ & $68.27^{\mathrm{b}}$ \\
\hline & $\mathrm{F} 2$ & $1.31^{\mathrm{b}}$ & $3.80^{\mathrm{a}}$ & $1.05^{\mathrm{a}}$ & $2.07^{\mathrm{a}}$ & $87.14^{\mathrm{a}}$ \\
\hline & F3 & $1.70^{\mathrm{a}}$ & $3.10^{\mathrm{b}}$ & $1.02^{\mathrm{a}}$ & $1.82^{\mathrm{b}}$ & $69.71^{\mathrm{b}}$ \\
\hline \multirow{5}{*}{$\begin{array}{l}\text { Plain river } \\
\text { network } \\
\text { area }\end{array}$} & W0 & $0.66^{\mathrm{a}}$ & $8.64^{a}$ & $3.35^{\mathrm{a}}$ & $4.25^{\mathrm{a}}$ & $114.28^{\mathrm{a}}$ \\
\hline & W1-PR & $0.64^{\mathrm{a}}$ & $7.00^{\mathrm{b}}$ & $1.63^{\mathrm{b}}$ & $2.94^{\mathrm{b}}$ & $63.69^{\mathrm{b}}$ \\
\hline & W2-PR & $0.17^{\mathrm{b}}$ & $3.16^{\mathrm{c}}$ & $1.13^{\mathrm{c}}$ & $1.54^{\mathrm{c}}$ & $61.14^{\mathrm{b}}$ \\
\hline & F2 & $0.46^{\mathrm{a}}$ & $6.39^{\mathrm{a}}$ & $2.30^{\mathrm{a}}$ & $3.07^{\mathrm{a}}$ & $77.74^{\mathrm{a}}$ \\
\hline & F3 & $0.52^{\mathrm{a}}$ & $6.14^{\mathrm{a}}$ & $1.77^{\mathrm{b}}$ & $2.76^{\mathrm{a}}$ & $81.67^{\mathrm{a}}$ \\
\hline
\end{tabular}

\subsection{Water savings and pollution reduction mechanism}

SEM is a method to establish, estimate and test causality model ${ }^{[27]}$. In order to clarify the impact mechanism of field irrigation and drainage regulation on water savings and pollution reduction, SEM was used to analyze the causality between irrigation water amount, WUE, non-point source pollution reduction and crop yield. The results of SEM and path analysis are shown in Figure 6, and the fitting results of model parameters 
are listed in Table 5. IRA had a significant positive impact on WCA, WUE $E_{\mathrm{ET}}, \mathrm{COD}$, and $\mathrm{NH}_{4}{ }^{+} \mathrm{-}$, but a significant negative impact on $\mathrm{WUE}_{\mathrm{I}}$ and yield. WCA had a significant positive impact on yield but a significant negative impact on $\mathrm{WUE}_{\mathrm{I}}$ and $\mathrm{WUE}_{\mathrm{ET}}$. $\mathrm{WUE}_{\mathrm{I}}$ had a significant positive impact on $\mathrm{WUE}_{\mathrm{ET}}$, but a significant negative impact on yield. $\mathrm{WUE}_{\mathrm{ET}}$ had a significant positive effect on $\mathrm{NH}_{4}{ }^{+} \mathrm{N}$, and $\mathrm{NH}_{4}{ }^{+}-\mathrm{N}$ had a significant positive effect on COD. The analysis of remediation effect was shown in Table 6. The path of IRA $\rightarrow \mathrm{NH}_{4}{ }^{+}-\mathrm{N} \rightarrow \mathrm{COD}$ presented partial remediation effect, that was, the impact mechanism of IRA on COD, partly through IRA on COD, partly through the intermediary variable $\mathrm{NH}_{4}{ }^{+}-\mathrm{N}$, and the effect size was $23.6 \%$. The path of $\mathrm{IRA} \rightarrow \mathrm{WUE}_{\mathrm{I}} \rightarrow \mathrm{WUE}_{\mathrm{ET}}$ presented a full remediation effect, that was the influence mechanism of IRA on WUE $E_{\mathrm{ET}}$, IRA affected the intermediary variable $\mathrm{WUE}_{\mathrm{I}}$, firstly, and then intermediary variable WUE $_{I}$ affected WUE $\mathrm{ET}_{\mathrm{ET}}$. The path of $\mathrm{IRA} \rightarrow \mathrm{WCA} \rightarrow \mathrm{WUE}_{\mathrm{ET}}$ presented suppression effect, which would increase the total effect between independent variables and dependent variables, that was, after controlling the masking variable WCA, the effect of IRA on WUE $_{\mathrm{ET}}$ would be strengthened. The path of IRA $\rightarrow$ WCA $\rightarrow \mathrm{WUE}_{\mathrm{I}}$ presented a partial remediation effect, this was, the impact mechanism of IRA on $W_{U} E_{I}$, part of which directly affected $W_{U}$ through IRA and part of which affected $\mathrm{WUE}_{\mathrm{I}}$ through the intermediary variable WCA, and the effect size was $38.1 \%$.

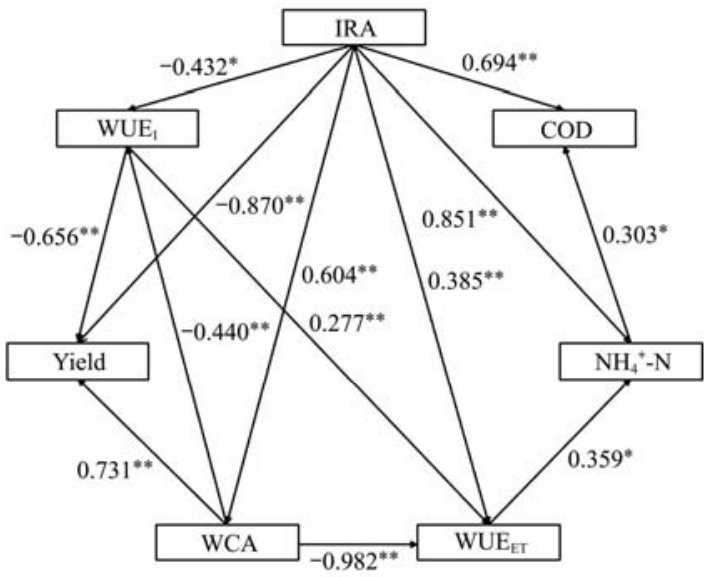

Note: IRA represents irrigation amount; WCA represents water consumption amount; the number in the figure is the standardized path coefficient; and the * sign indicates significance $(* p<0.05, * * p<0.01)$

Figure 6 Path analysis on irrigation amount, WUE, pollution reduction and yield of controlled irrigation and drainage in paddy field

Table 5 Fitting indexes of structural model

\begin{tabular}{ccccccccccccc}
\hline Index & $\chi^{2}$ & df & $p$ & $\chi^{2} / \mathrm{df}$ & GFI & RMSEA & RMR & CFI & NFI & NNFI \\
\hline Standard & -- & -- & $>0.05$ & $<3$ & $>0.9$ & $<0.10$ & $<0.05$ & $>0.9$ & $>0.9$ \\
Value & 13.805 & 8 & 0.087 & 1.726 & 0.995 & 0.072 & 0.001 & 0.964 & 0.925 & 0.907 \\
\hline
\end{tabular}

Table 6 Effect analysis of remediation role

\begin{tabular}{|c|c|c|c|c|c|c|c|c|}
\hline $\mathrm{X} \rightarrow \mathrm{M} \rightarrow \mathrm{Y}$ & $\mathrm{c}$ & $\mathrm{a}$ & $\mathrm{b}$ & $a \times b$ & $95 \%$ BootCI & $\mathrm{c}^{\prime}$ & Test result & Effect size \\
\hline $\mathrm{IRA} \rightarrow \mathrm{NH}_{4}^{+}-\mathrm{N} \rightarrow \mathrm{COD}$ & $0.937^{* *}$ & $0.671^{* *}$ & $0.329^{*}$ & 0.221 & -0.048 to 0.541 & $0.716^{* *}$ & Partial remediation & $23.6 \%$ \\
\hline $\mathrm{IRA} \rightarrow \mathrm{WUE}_{\mathrm{I}} \rightarrow \mathrm{WUE}_{\mathrm{ET}}$ & -0.310 & $-0.773^{* *}$ & $0.568^{* *}$ & -0.439 & -0.888 to -0.334 & 0.128 & Full remediation & $100 \%$ \\
\hline $\mathrm{IRA} \rightarrow \mathrm{WCA} \rightarrow \mathrm{WUE}_{\mathrm{ET}}$ & -0.310 & $0.406^{* *}$ & $-1.270^{* *}$ & -0.516 & -1.010 to -0.274 & $0.206^{* *}$ & Suppression effect & $250.7 \%$ \\
\hline $\mathrm{IRA} \rightarrow \mathrm{WCA} \rightarrow$ WUEI & $-0.773^{* *}$ & $0.406^{* *}$ & $-0.724^{*}$ & -0.294 & -0.616 to -0.039 & $-0.478 *$ & Partial remediation & $38.1 \%$ \\
\hline
\end{tabular}

Note: c represents the regression coefficient of X versus $\mathrm{Y}$ (when there is no intermediary variable $\mathrm{m}$ in the model), i.e., the total effect; a represents the regression coefficient of $\mathrm{X}$ versus $\mathrm{M}$; $\mathrm{b}$ represents the regression coefficient of $\mathrm{M}$ versus $\mathrm{Y}$, and $\mathrm{a} \times \mathrm{b}$ is the product of a and $\mathrm{b}$, that is, the intermediary effect; $95 \%$ BootCI represents the $95 \%$ confidence interval calculated by Bootstrap sampling; $\mathrm{c}^{\prime}$ represents the regression coefficient of $\mathrm{X}$ versus $\mathrm{Y}$ (when there is an intermediary variable $\mathrm{M}$ in the model), that is, the direct effect; and the $*$ sign indicates significance $\left(* p<0.05,{ }^{* *} p<0.01\right)$.

\section{Conclusions}

From the above results and discussions, we could draw the following conclusions.

1) DWC was lower for 2 kinds of controlled irrigation and drainage methods (W1 and W2) than that for conventional irrigation (W0) except at the beginning and end of growth period. Field water conditions could be improved for reducing field water consumption according to water level control. Irrigation quota in soaking period showed no significant effects in every typical area, while it was greatly affected by field water level control in growing period. Irrigation quota for W0 was $37.0 \%-71.7 \%$ higher than that for $\mathrm{W} 1$ and $\mathrm{W} 2$ in whole growth period of rice.

2) Rice growth and yield under $W 1$ and $W 2$ were significantly higher than those under W0, while W1 and W2 had no significant difference. Compared with W0, the average increase in the range of root length, DMA, LAI and yield under W1 or W2 were $2.3 \%$ $4.0 \%, 0.3 \%-12.5 \%, 4.4 \%-7.4 \%$, and $0.4 \%-2.1 \%$, respectively. Meanwhile, the crop growth and yield of F3 were slightly higher than that of F2. In addition, the yield of hybrid rice was $11.8 \%$ $26.7 \%$ higher than that of conventional rice.

3) Water consumption, water leakage and crop evapotranspiration were affected mainly by field water level regulation. While there is no significant difference betweenW1 and W2 themselves, they were $16.63 \%-34.40 \%, 39.97 \%-60.80 \%$, and $9.40 \%-31.53 \%$ lower than those under W0, respectively. The effect of fertilization times on water demand was not significant. In a typical area, $\mathrm{WUE}_{\mathrm{I}}$, and $\mathrm{WUE}_{\mathrm{ET}}$ for $\mathrm{W} 1$ and $\mathrm{W} 2$ were significantly higher, but $\mathrm{WUE}_{\mathrm{P}}$ was lower than that of W0, in different typical areas, the difference of WUE was mainly caused by the difference of rice varieties.

4) Nitrogen was the main pollution in surface water and groundwater, while phosphorus accounts for a lower proportion. The surface nitrogen loss was mainly $\mathrm{NH}_{4}{ }^{+} \mathrm{N}$, and the groundwater nitrogen loss was mainly $\mathrm{NO}_{3}{ }^{-}-\mathrm{N}$. The total pollution load of TN, $\mathrm{NO}_{3}{ }^{-}-\mathrm{N}, \mathrm{NH}_{4}{ }^{+}-\mathrm{N}$ and $\mathrm{COD}$ was significantly reduced for $\mathrm{W} 1$ and W2 than that for W0. TP, TN, $\mathrm{NO}_{3}{ }^{-}-\mathrm{N}, \mathrm{NH}_{4}{ }^{+}-\mathrm{N}$ and COD loss in field surface drainage accounted for $99.2 \%, 80.2 \%, 74.7 \%, 91.0 \%$ and $76.5 \%$ at hilly area, $89.3 \%, 69.6 \%, 22.8 \%, 83.4 \%$ and $89.1 \%$ at coastal plain area, $92.5 \%, 84.1 \%, 75.3 \%, 83.2 \%$ and $83.0 \%$ at plain river network area, respectively.

5) The structural equation model was established for IRA, WCA, WUE, pollution reduction and crop yield in typical areas of Zhejiang Province in China. The path analysis showed that IRA had a significant positive impact on WCA, WUE $E_{\mathrm{ET}}, \mathrm{COD}$ and $\mathrm{NH}_{4}{ }^{+}-\mathrm{N}$, but a significant negative impact on $\mathrm{WUE}_{\mathrm{I}}$ and yield. 
WCA had a significant positive impact on yield but a significant negative impact on $\mathrm{WUE}_{\mathrm{I}}$ and $\mathrm{WUE}_{\mathrm{ET}}$. $\mathrm{WUE}_{\mathrm{I}}$ had a significant positive impact on $\mathrm{WUE}_{\mathrm{ET}}$ but a significant negative impact on yield. WUE $E_{\mathrm{ET}}$ had a significant positive effect on $\mathrm{NH}_{4}{ }^{-}-\mathrm{N}$, and $\mathrm{NH}_{4}{ }^{+}-\mathrm{N}$ had a significant positive effect on COD.

6) The significance of farmland water level regulation in water abundant areas in southern China lies not only in water savings but also in reducing drainage and non-point source pollution. Its core is to increase rainfall retention depth and time by controlling the upper limit of rainfall storage, which can reduce water discharge and the concentration of non-point source pollutants. Especially from jointing and booting stage to the heading and flowering stage, the upper limit of rainfall storage can be controlled at 100-120 mm in the hilly area, and controlled at $150-200 \mathrm{~mm}$ in the plain area.

\section{Acknowledgements}

The authors acknowledge that this research was financially supported by the National Key Research and Development Program (Grant No. 2019YFC0408803), the National Natural Science Foundation of China (Grant No. 52009044), and the Basic Public Welfare Research Project of Zhejiang Province (Grant No. LGN20E090001).

\section{[References]}

[1] Wang W, Yu Z, Wei Z, Shao Q, Xu J. Responses of rice yield, irrigation water requirement and water use efficiency to climate change in china: historical simulation and future projections. Agricultural Water Management, 2014; 146: 249-261.

[2] Guo Y, Shen Y. Agricultural water supply/demand changes under projected future climate change in the arid region of northwestern China. Journal of Hydrology, 2016; 540: 257-273.

[3] He Y, Zhang J, Yang S, Hong D, Xu J. Effect of controlled drainage on nitrogen losses from controlled irrigation paddy fields through subsurface drainage and ammonia volatilization after fertilization. Agricultural Water Management, 2019; 221: 231-237.

[4] Aryal N, Reba M L. Transport and transformation of nutrients and sediment in two agricultural watersheds in Northeast Arkansas. Agriculture Ecosystems \& Environment, 2017; 236: 30-42

[5] Hoseinian Y, Bahmanyar M A, Sadegh-Zade F, Emadi M, Biparva P. Effects of different sources of silicon and irrigation regime on rice yield components and silicon dynamics in the plant and soil. Journal of Plant Nutrition, 2020; 43(15): 2322-2335.

[6] Darzi-Naftchali A, Ritzema H, Karandish F, Mokhtassi-Bidgoli A, Ghasemi-Nas M. Alternate wetting and drying for different subsurface drainage systems to improve paddy yield and water productivity in Iran. Agricultural Water Management, 2017; 193: 221-231.

[7] Hu Q, Yang Y, Han S, Yang Y, Ai Z, Wang J, et al. Identifying changes in irrigation return flow with gradually intensified water-saving technology using hydrus for regional water resources management. Agricultural Water Management, 2017; 194: 33-47.

[8] Xiao M H, Li Y Y, Wang J W, Hu X J, Wang J W, Miao Z M. Study on the law of nitrogen transfer and conversion and use of fertilizer nitrogen in paddy fields under water-saving irrigation mode. Water, 2019; 11(2): 218. doi: $10.3390 / \mathrm{w} 11020218$.

[9] Tan X, Shao D, Liu H, Yang F, Xiao C, Yang H. Effects of alternate wetting and drying irrigation on percolation and nitrogen leaching in paddy fields. Paddy and Water Environment, 2013; 11(1): 381-395.

[10] Martini L, Mezzomo R F, Avila L, Massey J H, Marchesan E, Zanella R, et al. Imazethapyr and imazapic runoff under continuous and intermittent irrigation of paddy rice. Agricultural Water Management, 2013; 125: 26-34.

[11] Guo X, Huang S, Wang Z, Wang F, Chen B. Impact of different irrigation methods on resistance of rice against bending and breaking. Journal of Irrigation and Drainage, 2017; 36(5): 1-5.

[12] Guo X, Yuan J, Guo F, Chen Z. Preliminary study on water-catching and controlled irrigation technology of rice. Transactions of the CSAE, 2009; 25(4): 70-73. (in Chinese)

[13] Qiu C, Shao C, Guan X, Qian Y, Chen J, Zhang T, et al. Effects of water-saving irrigation on farmland ecology and water and fertilizer utilization in double cropping late rice. Acta Agriculturae Bireali-occidentails Sinica, 2018; 27(4): 509-517.

[14] Li Y Y, Wen T, Zhu G X, Shao X H. Water and fertilizer utilization and characteristics of rice root growth under rain-water storage irrigation. Int J Agric \& Biol Eng, 2020; 23(1): 7-14.

[15] Omer A R, Czarnecki J, Baker B H, Hogue J A. Characterizing nitrogen outflow from pre-harvest rice field drain events. Agricultural Water Management, 2016; 165: 44-49.

[16] Gao S K. Effect of different controlled irrigation and drainage regimes on crop growth and water use in paddy rice. International Journal of Agriculture and Biology, 2018; 20(3): 486-492

[17] Shao G C, Deng S, Liu N, Yu S E, Wang M H, She D L. Effects of controlled irrigation and drainage on growth, grain yield and water use in paddy rice. European Journal of Agronomy, 2014; 53: 1-9.

[18] Xiao M H, Yu S E, She D L, Hu X J, Chu L L. Nitrogen and phosphorus loss and optimal drainage time of paddy field under controlled drainage condition. Arabian Journal of Geosciences, 2015; 8: 4411-4420.

[19] Kröger R, Cooper C M, Moore M T. A preliminary study of an alternative controlled drainage strategy in surface drainage ditches: Low-grade weirs. Agricultural Water Management, 2008; 95(6): 678-684.

[20] State Environmental Protection Administration of China. Water and wastewater monitoring analysis method (The Fourth Edition). Beijing: China Environmental Science Press, 2002; 784p.

[21] Won J G, Choi J S, Lee S P, Son S H, Chung S O. Water saving by shallow intermittent irrigation and growth of rice. Plant Production Science, 2005; 8(4): 487-492.

[22] Le X Q, Tinh N V, Matsuda S, Kadota K, Seiichiro Y. Effect of organizational paddy water management by a water user group on methane and nitrous oxide emissions and rice yield in the Red River Delta, Vietnam. Agricultural Water Management, 2019; 217: 179-192.

[23] Yuan S, Peng S, Li T. Evaluation and application of the oryza rice model under different crop managements with high-yielding rice cultivars in central China. Field Crops Research, 2017; 212: 115-125.

[24] Wang W G, Peng S Z, Sun F C, Xing W Q, Xu J Z. Spatiotemporal variations of rice irrigation water requirements in the mid-lower reaches of Yangtze River under changing climate. Advances in Water Science, 2012; 23(5): 656-664. (in Chinese)

[25] Peng S Z, Ai L K, He Y P, Zhang J G, Yang S H. Effect of irrigation and drainage coupling management on rice water requirement. Journal of Hydraulic Engineering, 2014; 45(3): 320-325. (in Chinese)

[26] Xiao M H, Yu S E, Zhang Y L. Changes of nitrogen concentration for surface and groundwater in flooding paddy field under controlled drainage. Transactions of the CSAE, 2011; 27(10): 180-186. (in Chinese)

[27] Selonen V, Helle S, Laaksonen T. Identifying the paths of climate effects on population dynamics: dynamic and multilevel structural equation model around the annual cycle. Oecologia, 2021; 195(2): 525-538. 